\title{
17 The role of mechanization in transformation of smallholder agriculture in Southern Africa
}

\author{
Experience from Zimbabwe \\ Frédéric Baudron, Raymond Nazare \\ and Dorcas Matangi
}

This chapter will explore "the why", "the what" and "the how" of mechanization for smallholder farmers in Southern Africa, using Zimbabwe as an example, and is based on the experience of the ACIAR-funded project "Farm Mechanization and Conservation Agriculture for Sustainable Intensification" (FACASI, www.facasi.act-africa.org) and the UNDP-funded project "Program for Resilience and Growth" (PROGRESS).

\section{Why mechanization? Evidence of labour as a major limiting factor to the productivity of farming systems in Southern Africa}

Per capita food production in Southern Africa has declined dramatically in the last half-century (Pretty et al., 2011), highlighting the need for intensification in the region. In addition, the need to foster a new form of intensification often coined "sustainable intensification" (SI) - one that increases agricultural production and productivity while minimizing detrimental economic, social and environmental outcomes - is widely recognized (Vanlauwe et al., 2014). By definition, intensification (whether conventional or sustainable), is a process of increasing agricultural output. This increase is generally accompanied by an increase in farm power demand, to handle greater volumes during harvest, transport and processing (Clarke and Bishop, 2002). In addition, the implementation of SI technologies tends to increase management and precision requirements, thus resulting in increased labour demand in a context of low mechanization. For example, precise application of fertilizer manually (as in the case of micro-dosing) increases labour demand compared with fertilizer banding (Babiker et al., 2017). Similarly, timely weeding is often conditioned by labour availability (Orr et al., 2002). Management practices intended to improve the quantity and quality of manure also tend to be highly labour intensive (Harris, 2002). In manual conservation agriculture (CA) production systems, labour demand for land preparation and weeding is much higher than for conventional production systems (Rusinamhodzi, 2015). Finally, the adoption of agroforestry technologies - such as alley cropping - has been found to be 
limited by high labour demand for, e.g., pruning (Hoekstra, 1987). The positive impact on productivity of precise fertilizer application, timely weeding, CA, agroforestry and many other SI technologies is well known, but their impact on labour demand, which may limit their adoption in the context of Southern Africa where mechanization levels are low, is rarely acknowledged. This lack of consideration for labour issues emanates from the perception that labour in smallholder systems of Southern Africa is abundant and thus nonlimiting. This view is also fueled by macroeconomic analyses (of e.g., land:labour ratio; Headey and Jayne, 2014), which are based on national data that may be too aggregated to reveal farm-level dynamics (Baudron et al., 2019).

Several lines of evidence point to the fact that labour and farm power are increasingly becoming major limiting factors to the productivity of smallholder systems in Southern Africa (Baudron et al., 2015) and most likely a significant constraint to the adoption of SI technologies (which are labour intensive, as demonstrated earlier). To illustrate this point, we use data collected under the FACASI project in two contrasting sites of Zimbabwe: Domboshawa and Makonde.

The attainable land productivity (maximum land productivity a farm can achieve considering all grains, roots and tubers produced on-farm) appears correlated to total labour used on-farm in these two sites (Figure 17.1), which clearly demonstrates that labour/farm power is a major limiting factor to the productivity of the production systems considered. This, associated with the growing scarcity (and cost) of rural labour - in particular because of rural-urban migration (Collier, 2017) - points to the need for mechanization to increase

DOMBOSHAWA

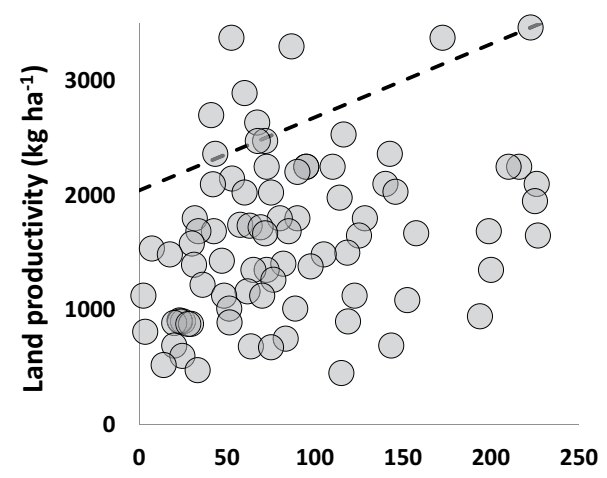

MAKONDE

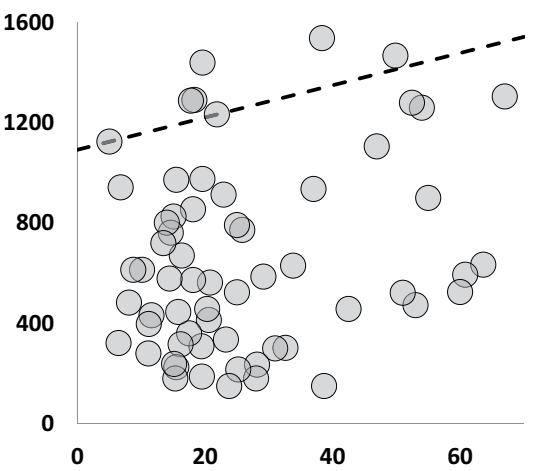

Total labour (person.day.ha-1)

Figure 17.1 Land productivity (considering all grains, roots and tubers produced on-farm) as a function of total labour (per unit of farm area) for Domboshawa and Makonde; dashed lines represent linear regressions fitted through the 90th percentile (i.e., "boundary line") 


\section{Frédéric Baudron et al.}

the productivity of smallholder agriculture in Southern Africa. Mechanization is also expected to reduce the postharvest losses currently experienced by smallholders in the region (Tefera, 2012) and reduce drudgery, which is disproportionately placed on women (Baudron et al., 2019).

The form mechanization should take in the smallholder farming systems of Southern Africa is the subject of much debate. Smallholder farms in the region tend to be small and fragmented $(0.79 \pm 0.46$ ha in Domboshawa and $4.63 \pm 3.10$ ha in Makonde for example). The use of (relatively) large (two axle) tractors would thus require land consolidation. Some authors have argued that consolidation is a prerequisite to mechanization, to use large tractors efficiently (e.g., Asiama et al., 2017). In contrast, others have argued for a concept of "appropriate mechanization", whereby machines are adapted to farm size and not the opposite (e.g., Baudron et al. 2015). This is because of the negative social (e.g., labour displacement; Binswanger et al., 1995) and environmental (e.g., loss of landscape heterogeneity; Benton et al., 2003) consequences of land consolidation and because of negative farm size productivity relationships often reported in smallholder farming systems in Africa (Ali and Deininger, 2015; Baudron et al., 2019).

The use of animal traction is part of appropriate mechanization. However, draught animals are uncommon in large parts of Southern Africa, with most oxen concentrated in the central plateau of Zimbabwe, Southern Zambia and the highlands of Malawi. Elsewhere, diseases such as trypanosomiasis restrict the presence of oxen. Even in regions where draught animals are commonly used, their numbers tend to decline because of the combined effect of epidemics (in particular tick-borne diseases such as the East Coast fever), recurring droughts and feed shortages (Mapiye et al., 2009; Moyo et al., 2017).

Thus, it could be argued that the need for smallholder mechanization in Southern Africa combined with the presence of small and fragmented fields and the diminishing availability of animal traction calls for small (less than 25 horsepower) motorized solutions. Such mechanization pathways successfully took place in countries like Bangladesh. Despite very small and fragmented fields, Bangladesh agriculture is highly mechanized, but power is delivered by hundreds of thousands of small (single axle) tractors and other small engines, not large (two-axle) tractors (Biggs et al., 2011). Such pattern of mechanization guided the projects FACASI and PROGRESS in exploring the potential impact of appropriate mechanization based on two-wheel tractors for smallholder in Zimbabwe (and other areas of Eastern and Southern Africa). The next section will explore what tasks should be mechanized in priority and what commercially available two-wheel tractor ancillary equipment is available for that.

\section{What task(s) to mechanize? With what commercially available machines?}

Land preparation is the most power-intensive farming operation in rainfed agriculture (Lal, 2004). It is also one of the most critical operation in Southern Africa, as delayed land preparation and delayed planting often result in severe 
yield penalties in the region (Nyagumbo et al., 2017). In addition, during focus group discussions organized under the FACASI project, it was stated consistently in all sites - including Domboshawa and Makonde in Zimbabwe - and by both men and women that mechanizing land preparation and crop establishment is a priority (Baudron et al., 2019). Indeed, although land preparation is a men's task, the quality and timeliness of this operation was said to also affect weeding intensity, one of the main tasks carried out by women. Un-mechanized land preparation was also said to take several days, affecting the labour burden of women who have to prepare food and transport it to men in the field during that period.

Two-wheel tractors can be used to plough light (e.g., sandy) soils (Kebede and Getnet, 2016) but do not produce enough traction to plough heavier soils in rainfed conditions (Holtkamp and Lorenz, 1990; Singh, 2006). However, twowheel tractors could be used to establish a crop in these soils providing energy requirements for tillage are reduced. This can be achieved by simplifying land preparation i.e., using reduced or no tillage, which cuts energy requirements by about half compared to conventional (i.e., mouldboard or disc ploughing) land preparation (Lal, 2004). Therefore, it could be argued that reduced or no tillage could make the use of two-wheel tractors for crop establishment viable in most of Southern Africa.

Several direct seeders (i.e., placing seed and fertilizer without prior tillage) for two-wheel tractors are now commercially available, from countries such as China and Brazil and can be used to seed most large grain (e.g., maize, cotton) and small grain crops (e.g., wheat, rice). Local manufacturers - including Zimplow LTD (Figure 17.2a) have also started manufacturing direct seeders for two-wheel tractors.
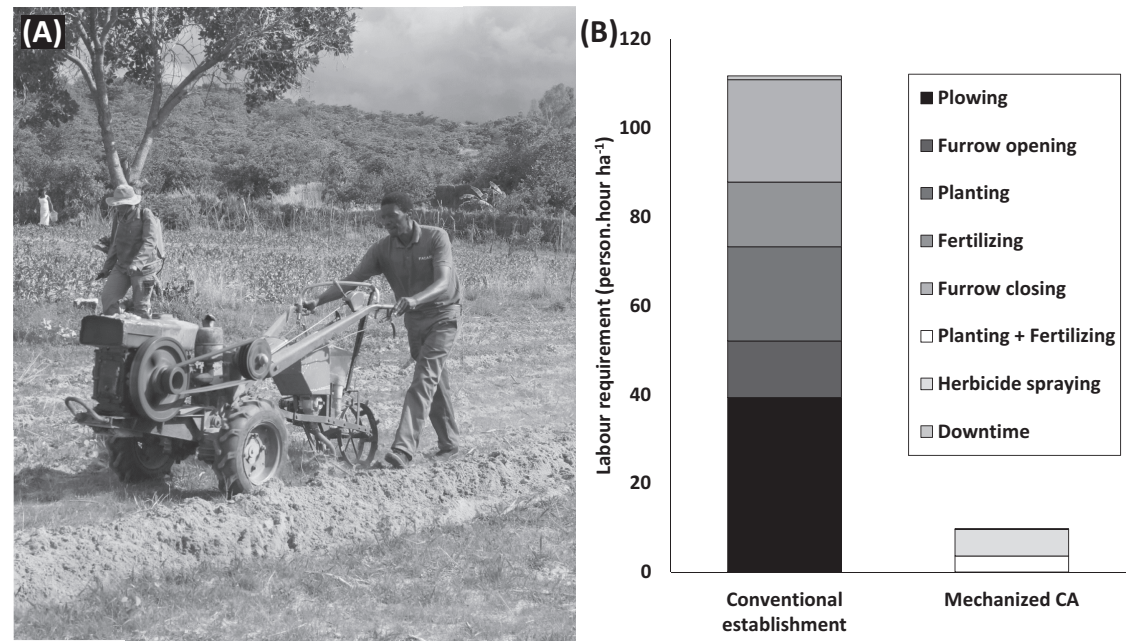

Figure 17.2 a) direct seeding with a Zimplow single row seeder powered by a $12 \mathrm{HP}$ twowheel tractor and b) labour per task required to establish a maize crop conventionally vs. using mechanized CA (Zimplow single row seeder) 
During the 2017/18 season in Eastern Zimbabwe, (Figure 17.2b) the use of a Zimplow single row seeder was found to reduce labour requirements to establish a crop of maize from 111.8 person.hour ha ${ }^{-1}$ to 9.7 person.hour ha-1 compared to conventional crop establishment (ox ploughing and lining followed by manual placement of seeds and fertilizers). This corresponds to a reduction by a factor 11.5. The mean fuel consumption was low, at $3.4 \pm 1.2 \mathrm{~L} \mathrm{ha}^{-1}$.

Direct seeding using a two-wheel tractor was not found to impact maize yield significantly, except in few cases. This may be due to the fact that only low quantities of crop residues tend to be used as mulch. The improvement of soil conditions under CA also tend to take several years (Thierfelder et al., 2015). Nevertheless, by saving time, labour and cost, direct seeding using a two-wheel tractor appears to be profitable for users. Shelling and transport were other mechanized operation considered by FACASI and PROGRESS, for small engines to be in productive use for a greater part of the year and to increase the profitability of mechanization (and reduce the unit cost of custom work in the case of service provision).

From the results presented in this section, small mechanization clearly has a place in the SI basket of technologies for smallholders in Southern Africa. The next section will explore modalities to deliver small mechanization to smallholders in the region for the greatest number to benefit.

\section{How to deliver mechanization in different contexts?}

An ex ante analysis conducted in Makonde and Domboshawa revealed that the use of two-wheel tractors and their accessories was not economically viable for farmers as individual owners, operating solely on their own farms, or on their own farms and neighbouring farms (Table 17.1). However, the same analysis revealed that small mechanization could be an attractive investment for individual farmers if they provide services to neighbouring farmers at commercial rates on a full-time basis and ensure demand. Such a model - based on service

Table 17.1 Net present values (NPV), benefit cost ratios (B/C) and internal rates of return (IRR) calculated from ex ante analysis for three business models, providing for a combination of planting, shelling and transporting operations in Zimbabwe

\begin{tabular}{llcc}
\hline Business models & Indicators & Makonde & Domboshawa \\
\hline Farmer operator solely working & NPV (US\$) & -9207 & -8649 \\
on his/her farm & B/C ratio & 0.2 & 0.11 \\
& IRR (\%) & - & - \\
Farmer operator working on & NPV (US\$) & -4154 & -4862 \\
neighbouring farms & B/C ratio & 0.89 & 1.8 \\
Full time service provider & IRR (\%) & 2 & 9 \\
& NPV (US\$) & 18446 & 4307 \\
& B/C ratio & 1.3 & 1.2 \\
\hline
\end{tabular}


hiring - appears viable in Zimbabwe as the large majority of farmers in the region currently hire labour, and many of them also hire animal traction services or tractor services. For example, 94 and 97\% of farming household hire labour in Domboshawa and Makonde, respectively.

After five years of implementation of the FACASI project in Makonde, an ex-post analysis was also conducted to evaluate the performance of various hired service business models combining different operations (Table 17.2). Results of the study show that, when averaged for two years, all the business models are profitable as demonstrated by positive net present values and benefit-cost ratios greater than 1. Profitability is particularly high during years with maximum business (Table 17.2). These high performances are achieved through aggressive marketing of services and an established clientele base. In contrast, years with low business typically have low profit margins and even losses for some business models. This is particularly so for planting services, which is timebound and may end-up being unprofitable in very dry or very wet years that only allow planting for a few days

Additionally, the results also indicate that service providers offering more than one service i.e., more implements, tend to be profitable in all scenarios considered. This suggests that businesses can complement each other, as demonstrated by the combination of planting and shelling (Table 17.2). The findings of this study are consistent with Kahan et al. (2017) who observed that profitability was higher for a service provider offering a range of services compared to one offering a single service. Bundling of services increases capacity utilization of the tractor, as it is the major source of power for these services. Offering more than one service is, however, dependent on the capacity of the SP to invest in additional implements, affordability and access to financial resources. Thus, business model performance is dependent on the actors and is context specific.

Table 17.2 Average, minimum and maximum profitability - assessed by net present values (NPV), benefit cost ratios (B/C) and internal rates of return (IRR) for business models combining different operations in Makonde

\begin{tabular}{lccc}
\hline Indicators & 2WT-power sheller & 2WT Planter + sheller & 2WT Planter \\
\hline Average & & & \\
NPV (US\$) & 17679.2 & 21778.9 & 1763.2 \\
B/C ratio & 4 & 2.6 & 1.17 \\
IRR (\%) & $172 \%$ & $106 \%$ & $30 \%$ \\
Minimum & & & \\
NPV (US\$) & 18033.2 & 16740.9 & -3628.8 \\
B/C ratio & 4.1 & 2.4 & 0.58 \\
IRR (\%) & $175 \%$ & $88 \%$ & $-6 \%$ \\
Maximum & & & 7155.2 \\
NPV (US\$) & 17325.2 & 26816.9 & 1.62 \\
B/C ratio & 4 & 2.8 & $58 \%$ \\
IRR (\%) & $169 \%$ & $106 \%$ & \\
\hline
\end{tabular}


Table 17.3 Cost of planting and shelling using draught animals and labour (conventional practices) or using two-wheel tractor-based mechanization

\begin{tabular}{llll}
\hline Operations & Conventional practices & Mechanized practices & $\%$ Reduction \\
\hline Planting (US\$) & 120 & 56 & $53 \%$ \\
Shelling (US\$) & 129.6 & 97.5 & $25 \%$ \\
\hline
\end{tabular}

The ex-post analysis also evaluated the benefits that accrue to farmers in terms of cost saving through receiving mechanized services (Table 17.3). The results demonstrate that mechanized planting is more attractive to farmers (clients) than postharvest operations. The fact that the opposite is true for service providers (Table 17.2) raises questions as to the interventions that are necessary to scale small mechanization in Zimbabwe. Considering the high cost of planters, government may need to intervene with some incentives for service providers to acquire them in order for the largest number of farmers to benefit from this service (Benin et al., 2013).

\section{Conclusions: lessons learned}

Transforming smallholder agriculture in Southern Africa will require an improvement in access to farm power. Evidences presented in this chapter demonstrate that mechanization in the region can be delivered by service providers using small engines. This approach should be prioritized in area characterized by: 1) relatively commerce-oriented agriculture (e.g., presence of cash crops);2) agriculture constrained by labour shortages, at least seasonally; 3 ) high cost of maintaining draught animals (e.g., feed shortage); 4) field accessibility (e.g., feeder roads); 5) existence of hire services (e.g., ox ploughing); 6) relatively deep and stone-free soils; and 7) small and fragmented fields. For small mechanization interventions to be successful, it is crucial to involve private sector stakeholders - dealers, manufacturers, etc. - in every step. Incentive schemes (matching grants, soft loans, guarantee funds, etc.) are necessary to set up service providers in business. It should also be noted that an approach centred on the private sector alone may not work when targeting marginal areas (e.g., rain fed systems dominated by staples), marginal groups (e.g., resource-constrained smallholders), technologies providing public goods (e.g., conservation agriculture) or complex technologies (not a "product"). In such circumstances, the public sector has a crucial role to play in commercialization, in particular through the creation of a conducive business environment to attract private sector actors.

\section{References}

Ali, Daniel Ayalew, and Klaus Deininger. 2015. “Is There a Farm Size-Productivity Relationship in African Agriculture? Evidence from Rwanda." Land Economics 91 (2): 317-343. https://doi.org/10.3368/le.91.2.317. 
Asiama, Kwabena Obeng, Rohan Bennett, and Jaap Zevenbergen. 2017. "Land Consolidation for Sub-Saharan Africa's Customary Lands - The Need for Responsible Approaches." American Journal of Rural Development 5 (2): 39-45. https://doi.org/10.12691/AJRD-5-2-2.

Babiker, Monirah, Mohamed Arbab, Yassin Mohmad, and Ibrahim Dagash. 2017. "Microdosing Technology of Fertilizer for Sorghum Production At." Cell Biology E Development 1 (1): 18-22. https://doi.org/10.13057/cellbioldev/t010104.

Baudron, Frédéric, Brian Sims, Scott E Justice, David G Kahan, Richard Rose, Saidi Mkomwa, Pascal Kaumbutho, et al. 2015. "Re-Examining Appropriate Mechanization in Eastern and Southern Africa: Two-Wheel Tractors, Conservation Agriculture, and Private Sector Involvement." Food Security 7 (4): 889-904. https://doi.org/10.1007/s12571-015-0476-3.

Baudron, Frédéric, Michael Misiko, Bisrat Getnet, Raymond Nazare, John Sariah, and Pascal Kaumbutho. 2019. "A Farm-Level Assessment of Labour and Mechanization in Eastern and Southern Africa." Agronomy for Sustainable Development 5. https://doi.org/10.1007/ s13593-019-0563-5.

Benin, Samuel, Michael Johnson, Emmanuel Abokyi, Gerald Ahorbo, Kipo Jimah, Gamel Nasser, Victor Owusu, Joe Taabazuing, and Tenga Albert. 2013. "Revisiting Agricultural Input and Farm Support Subsidies in Africa: The Case of Ghana's Mechanization, Fertilizer, Block Farms, and Marketing Programs." IFPRI Discussion Paper no. 01300, November: 1-121. https://doi.org/10.13140/RG.2.2.23891.17447.

Benton, Tim G, Juliet A Vickery, and Jeremy D Wilson. 2003. "Farmland Biodiversity: Is Habitat Heterogeneity the Key?” Trends in Ecology \& Evolution 18 (4): 182-188. https:// doi.org/10.1016/S0169-5347(03)00011-9.

Biggs, Stephen, Scott E Justice, and David Lewis. 2011. "Patterns of Rural Mechanisation, Energy and Employment in South Asia: Reopening the Debate." Economic \& Political Weekly xlvi (9): 78-82.

Binswanger, H., K. Deininger, and G. Feder. 1995. "Power, Distortion, Revolts, and Reform in Agricultural Land Relations." Handbook of Development Economics 3 (3): 2659-2772.

Clarke, Lawrence, and Clare Bishop. 2002. "Farm Power - Present and Future Availability in Developing Countries." In Special Session on Agricultural Engineering and International Development in the Third Millennium. ASAE Annual International Meeting/CIGR World Congress, July 30, 2002. Chicago, USA. https://doi.org/10.1007/s11023-007-9060-8.

Collier, Paul. 2017. "African Urbanization: An Analytic Policy Guide." Oxford Review of Economic Policy 33 (3): 405-437. https://doi.org/10.1093/oxrep/grx031.

Harris, F. 2002. "Management of Manure in Farming Systems in Semi-Arid West Africa." Experimental Agriculture 38 (02): 131-148. https://doi.org/10.1017/S0014479702000212.

Headey, Derek D., and T. S. Jayne. 2014. "Adaptation to Land Constraints: Is Africa Different?” Food Policy 48: 18-33. https://doi.org/10.1016/j.foodpol.2014.05.005.

Hoekstra, Dirk A. 1987. "Economics of Agroforestry." Agroforestry Systems 5 (3): 293-300. https://doi.org/10.1007/BF00119127.

Holtkamp, R., and J. Lorenz. 1990. Small Four-Wheel Tractors for the Tropics and Subtropics: Their Role in Agriculture and Industrial Development. Technical. Bonn, Federal Republic of Germany.

Kahan, David, Roger Bymolt, and Fred Zaal. 2017. "Thinking Outside the Plot: Insights on Small-Scale Mechanisation from Case Studies in East Africa." Journal of Development Studies 00 (00): 1-16. https://doi.org/10.1080/00220388.2017.1329525.

Kebede, Laike, and Bisrat Getnet. 2016. "Performance of Single Axle Tractors in the SemiArid Central Part of Ethiopia." Ethiopian Journal of Agricultural Sciences 27 (1).

Lal, Rattan. 2004. "Carbon Emission from Farm Operations." Environment International. https://doi.org/10.1016/j.envint.2004.03.005. 
Mapiye, C., M. Chimonyo, and K. Dzama. 2009. "Seasonal Dynamics, Production Potential and Efficiency of Cattle in the Sweet and Sour Communal Rangelands in South Africa." Journal of Arid Environments 73 (4-5): 529-536. https://doi.org/10.1016/j. jaridenv.2009.01.003.

Moyo, I.A., T.N. Mudimba, D.N. Ndhlovu, S. Dhliwayo, S.M. Chikerema, and G. Matope. 2017. “Temporal and Spatial Patterns of Theileriosis in Zimbabwe: 2000-2014." Bulletin of Animal Health and Production in Africa 65 (3): 569-575. https://www.ajol.info/index.php/ bahpa/article/view/167662.

Nyagumbo, Isaiah, Siyabusa Mkuhlani, Walter Mupangwa, and Daniel Rodriguez. 2017. "Planting Date and Yield Benefits from Conservation Agriculture Practices across Southern Africa." Agricultural Systems 150: 21-33. https://doi.org/10.1016/j.agsy.2016.09.016.

Orr, A., B. Mwale, and D. Saiti. 2002. "Modelling Agricultural 'Performance': Smallholder Weed Management in Southern Malawi." International Journal of Pest Management 48 (4): 265-78. https://doi.org/10.1080/09670870210149808.

Pretty, Jules, Camilla Toulmin, and Stella Williams. 2011. "Sustainable Intensification in African Agriculture." International Journal of Agricultural Sustainability 9 (1): 5-24. https://doi. org/10.3763/ijas.2010.0583.

Rusinamhodzi, Leonard. 2015. “Tinkering on the Periphery: Labour Burden Not Crop Productivity Increased under No-till Planting Basins on Smallholder Farms in Murehwa District, Zimbabwe.” Field Crops Research 170: 66-75.

Singh, Gyanendra. 2006. "Agricultural Machinery Industry in India (Manufacturing, Marketing and Mechanization Promotion)." Status of Farm Mechanization in India, 154-174. http://scholar.google.com/scholar?hl=en\&btnG=Search\&q=intitle:Agricultural+Machi nery + Industry + in + India $+(+$ Manufacturing,++ marketing + and + mechanization + promo tion +$) \# 0$.

Tefera, Tadele. 2012. "Post-Harvest Losses in African Maize in the Face of Increasing Food Shortage." Food Security 4 (2): 267-277. https://doi.org/10.1007/s12571-012-0182-3.

Thierfelder, Christian, Rumbidzai Matemba-Mutasa, and Leonard Rusinamhodzi. 2015. "Yield Response of Maize (Zea Mays L.) to Conservation Agriculture Cropping System in Southern Africa." Soil and Tillage Research 146 (PB): 230-242. https://doi.org/ 10.1016/j.still.2014.10.015.

Vanlauwe, B., D. Coyne, J. Gockowski, S. Hauser, J. Huising, C. Masso, G. Nziguheba, M. Schut, and P. Van Asten. 2014. "Sustainable Intensification and the African Smallholder Farmer." Current Opinion in Environmental Sustainability 8: 15-22. https://doi.org/ 10.1016/j.cosust.2014.06.001.

\section{Further reading}

www.fao.org/waicent/FAOINFO/AGRICULT/againfo/programmes/documents/livatl2/ draftoxenmap.htm. 